\title{
WestVirginiaUniversity
}

THE RESEARCH REPOSITORY @ WVU

West Virginia Agricultural and Forestry Experiment

Davis College of Agriculture, Natural Resources

Station Bulletins

And Design

$1-1-1958$

\section{Reproduction in the West Virginia University dairy herds}

\author{
D. A. Hutchison
}

Robert Standish Dunbar

Follow this and additional works at: https://researchrepository.wvu.edu/ wv_agricultural_and_forestry_experiment_station_bulletins

\section{Digital Commons Citation}

Hutchison, D. A. and Dunbar, Robert Standish, "Reproduction in the West Virginia University dairy herds" (1958). West Virginia Agricultural and Forestry Experiment Station Bulletins. 412T.

https://researchrepository.wvu.edu/wv_agricultural_and_forestry_experiment_station_bulletins/642 @ WVU. It has been accepted for inclusion in West Virginia Agricultural and Forestry Experiment Station Bulletins by an authorized administrator of

The Research Repository @WVU. For more information, please contact ian.harmon@mail.wvu.edu. 


\section{BULLETIN 412T}

May 1958

\section{REPRODUCTION in the}

West Virginia University Dairy Herds

EST VIRGINIA UNIVERSITY AGRICULTURAL EXPERIMENT STATION 


\section{THE AUTHORS}

D. A. Hutchison was formerly Instructor and Assistant in Dairy Husbandry and is now County Agricultural Extension Agent, Marshall County; R. S. Dunbar, Jr., was formerly Associate Professor of Dairy Husbandry and Associate Dairy Husbandman and is now Associate Statistician in the Agricultural Experiment Station; and H. O. Henderson is Professor of Dairy Husbandry and Dairy Husbandman.

WEST VIRGINIA UNIVERSITY

Agricultural Experiment Station

College of Agriculture, Forestry, and Home Economics

A. H. Vanlandingham, Acting Director MORGANTOWN 


\section{Reproduction in the West Virginia University Dairy Herds}

D. A. HUTCHISON, R. S. DUNBAR, Jr., and H. O. HENDERSON

\section{Introduction}

CAILURE of dairy cows to reproduce with maximum efficiency re-sults in serious economic loss. When cows do not freshen regularly (approximately once each year) there is a loss in milk production, in the number of calves born, and in the number of animals from which replacements may be selected. Reproductive efficiency, or high and low fertility, are relative terms used to describe differences in the frequencies of successful pregnancies. In order that a dairyman may know how much emphasis to place on selection for reproductive efficiency relative to other traits of economic importance, it is necessary that he knows to what extent specific measures of reproductive efficiency are inherited.

The purpose of this work was to provide additional knowledge concerning the inheritance of specific measures of reproductive efficiency as well as to study the relationships among various aspects of reproduction of dairy cattle. Using the records of the cows in the West Virginia University dairy herds, an analysis was made of the sex ratio in the various herds, the number of twins, and the mortality of the calves, both when born singly and when born as twins. A study was made also of the length of the gestation period of the various breeds, together with estimates of its repeatability and heritability. Finally, the repeatability and heritability of certain measures of breeding efficiency of the cows in these herds were estimated.

\section{Procedure}

Breeding records used for this study were obtained from the West Virginia University herds, which included the Holstein and Jersey herds rom 1911 and the Ayrshire herd from 1917 to 1954. The number of inimals were 386 Ayrshires, 280 Holsteins, and 184 Jerseys-a total of 850 emales of breeding age. There were records of 4,105 services, 1,956 coneptions, and 1,580 gestations. 


\section{Results}

\section{THE RATIO OF BULL TO HEIFER CALVES}

\section{Single Births}

Of 1,719 single births in the West Virginia herds, 51.5 per cent were males. There were more males than females in both the Jersey ( 53.3 per cent) and Holstein (53.7 per cent) herds, but less in the Ayrshire (48.6 per cent) herd. These results are shown as ratios in Table 1 . This figure of 51.5 per cent males and 48.5 per cent females compared favorably with figures given by other investigators. For example, Johansson (17), using more than 124,000 birth records, found that 51.5 per cent were males, with neither significant variations between breeds nor for the age of the sire or dam. Gowen (12), in a study involving more than 200 herds, found that 50.5 per cent were males. Other investigators $(6,11,14,20)$ have reported figures which vary from 51.0 to 53.1 per cent males.

\section{TwIN BIRTHS}

During the period studied 80 calves were born as twins in the various herds. This was about 4.4 per cent of total births, or one set of twins to every 43 single births. This incidence of twinning varied slightly with the breeds. The Holstein breed had 5.6 per cent, the Jersey breed 4.6 per cent, and the Ayrshire breed 3.3 per cent twin births. The percentage of males to females was reversed in twin births, as compared to single births. Only 40.0 per cent of the twins of all breeds were males; Ayrshires 33.3 per cent, Holsteins 38.9, and Jerseys 50.0 (See Table I). Johansson (17), in a similar study, found an average of 96.3 twin males for every 100 twin females. He attributed the lower proportion of males as probably due to a large number of male young being expelled early in the gestation period. Nevertheless, the data reported here are insufficient to lead one to conclude that sex ratio is dependent on type of birth. Chi-square values approached but did not equal the 5 per cent probability level which would have led to a rejection of the hypothesis that sex and type of birth are independent characteristics of reproduction.

\section{MORTALITY}

Of the 1,719 single births, 5.7 per cent of the calves were born dead or died on the day of birth. Mortality was much greater among twins with 35.0 per cent of the 80 calves dead at birth, and the percentage of all calves dead at birth was 7.0 per cent. The mortalities of calves of the different breeds are presented in Table 2.

In the Jersey herd 14 twin calves either died or were dead at birth and only 6 were alive, which is a mortality of 70.0 per cent at birth 
Table 1. Sex Ratios of Calves by Type of Birth

\begin{tabular}{|c|c|c|c|c|c|c|c|c|}
\hline \multirow{2}{*}{ BREED } & \multirow{2}{*}{$\operatorname{Sex}$} & \multicolumn{3}{|c|}{ Number of Births } & \multicolumn{3}{|c|}{ Ratio Males to Females } & \multirow{2}{*}{$\begin{array}{l}\text { TWIN BIRTHS } \\
\text { PERCEAT OF } \\
\text { TOTAL }\end{array}$} \\
\hline & & SINGLE & TwiN & TOTAL & Single & TwiN & TOTAL & \\
\hline \multirow{2}{*}{ Ayrshire } & Male & 339 & 8 & 347 & 94.7 & 50.0 & 92.8 & 2.3 \\
\hline & Female & 358 & 16 & 374 & 100.0 & 100.0 & 100.0 & 4.3 \\
\hline \multirow{2}{*}{ Holstein } & Male & 327 & 14 & 341 & 116.0 & 63.6 & 112.2 & 4.1 \\
\hline & Female & 282 & 22 & 304 & 100.0 & 100.0 & 100.0 & 7.2 \\
\hline \multirow{2}{*}{ Jersey } & Male & 220 & 10 & 230 & 114.0 & 100.0 & 113.3 & 4.3 \\
\hline & Female & 193 & 10 & 203 & 100.0 & 100.0 & 100.0 & 4.9 \\
\hline \multirow{2}{*}{ All Breeds } & Male & 886 & 32 & 918 & 106.4 & 66.7 & 104.2 & 3.5 \\
\hline & Female & 833 & 48 & 881 & 100.0 & 100.0 & 100.0 & 5.4 \\
\hline Totals & & 1719 & 80 & 1799 & & & & 4.4 \\
\hline
\end{tabular}

Table 2. Mortality of Calves by Type of Birth

\begin{tabular}{|c|c|c|c|c|c|}
\hline \multirow{2}{*}{ BREED } & \multirow{2}{*}{$\begin{array}{l}\text { TYPE OF } \\
\text { BIRTH }\end{array}$} & \multicolumn{3}{|c|}{ Number of Calves } & \multirow{2}{*}{$\begin{array}{l}\text { PERCENT } \\
\text { DEAD } \\
\text { AT BIRTH }\end{array}$} \\
\hline & & Alive & DEAD & TOTAL & \\
\hline \multirow{3}{*}{ Ayrshire } & Singles & 665 & 32 & 697 & 4.6 \\
\hline & Twins & 18 & 6 & 24 & 25.0 \\
\hline & Total & 683 & 38 & 721 & 5.3 \\
\hline \multirow{3}{*}{ Holsteln } & Singles & 568 & 41 & 609 & 6.7 \\
\hline & Twins & 28 & 8 & 36 & 22.2 \\
\hline & Total & 596 & 49 & 645 & 7.6 \\
\hline \multirow{3}{*}{ Jersey } & Singles & 388 & 25 & 413 & 6.1 \\
\hline & Twins & 6 & 14 & 20 & $\tau 0.0$ \\
\hline & Total & 394 & 39 & 433 & 9.0 \\
\hline \multirow{3}{*}{ All Breeds } & Singles & 1621 & 98 & 1719 & 5.7 \\
\hline & Twins & 52 & 28 & 80 & 35.0 \\
\hline & Total & 1673 & 126 & 1799 & 7.0 \\
\hline
\end{tabular}


The Holstein herd averaged 22.2 per cent and the Ayrshire herd 25.0 per cent twin calves dead at birth. When all breeds were combined, it was found that they had given birth to 52 living twin calves and 28 dead twin calves. This difference in mortality of single and twin calves is highly significant statistically for each of the breeds and for all breeds combined. For some unknown reason the conditions in the uterus seem to be less favorable for twins than for single calves, and to some extent the male twin has a higher mortality rate than does the female.

The incidence of multiple births increased as the average age of the cow within a breed increased.

\section{WEIGHT OF CALVES AT BIRTH}

The weights of the calves at birth are given in Table 3. These weights were about the same as those reported by other workers $(8,9,25)$. The male calves were 5 to 10 per cent larger than the females and the twin calves much smaller than single born calves.

Table 3. Birth Weights of Calves (lbs.)

\begin{tabular}{|c|c|c|c|c|c|c|c|c|}
\hline \multirow[b]{2}{*}{ BREED } & \multicolumn{2}{|c|}{ MALE } & \multicolumn{2}{|c|}{ Female } & \multicolumn{2}{|c|}{ TWIN MALE } & \multicolumn{2}{|c|}{ TWIN FeMaLE } \\
\hline & No. & WEIGHT & No. & WEIGHT & No. & WEIGHT & No. & WEIGHT \\
\hline Ayrshire & 293 & 75.5 & 319 & 71.1 & 2 & 61.5 & 10 & 59.4 \\
\hline Holstein & 289 & 99.9 & 248 & 92.1 & 6 & 70.2 & 10 & 74.9 \\
\hline Jersey & 197 & 57.1 & 172 & 53.1 & - & - & 6 & 43.5 \\
\hline
\end{tabular}

\section{LENGTH OF GESTATION PERIOD}

A knowledge of the length of gestation in the dairy cow is of im. portance from a herd management standpoint because it enables the dairyman to give the cow proper preparation, such as drying off at proper time, getting her in proper physical condition for parturition anc subsequent lactation, and in feeding her for prevention of milk fever. The gestation period, in the past, has been considered to be 283 days However, recent studies $(2,3,11,13,16)$ have shown there is a definit difference among the breeds. The three breeds under consideration ir this study have an average gestation length of approximately 278 days

\section{Length of Gestation Period of Normal Calves}

There were 1,580 gestations resulting in the birth of a single, normal living calf, and 26 gestations producing living normal twin calves. Lengtl of gestation ranged from 239 to 321 days. There were 12 gestations o 260 days or less, and 21 gestations of 290 days or more. The three breed were all represented in the list of gestations of 260 days and less anc 290 days and over, with a fairly equal distribution among them. Tabl 4 shows that the average gestation periods were 278.2 days for the Ayr shire, 278.3 for the Holstein, and 277.5 for the Jersey herd. 
Effect of Sex on Length of Gestation Period

As shown in Table 4, there was no significant difference in the length of the gestation period associated with the sex of the fetus. The length of gestation of the males was slightly longer in both the Holstein and Jersey herds, but slightly shorter in the Ayrshire herd. When data for all breeds were pooled, the average length of gestation was 278.2 days for the males and 277.9 for the females. Other studies $(1,1 \mathrm{I})$ have shown that males are carried about one day longer than females, but the data in this study did not show this large a difference.

\section{Effect of Twins on Length of Gestation Period}

Herman et al. (13) and Knott (20) have reported that the length of twin gestations is shorter than that of single gestations, averaging about 272 days. The results of this study confirmed these findings (Table 4). The average length of twin-birth gestation for the three breeds was 273.8 days. Ayrshires averaged 276.1; Holsteins, 273.6; and Jerseys, 271.7 days.

\section{Effect of Age of Dam on Length of Gestation Period}

Herman et al. (13) and Knott (20) observed an increase in the length of gestation as the age of the dam increased. Brakel et al. (4) showed a highly significant difference of 1.46 days between the gestation length at 2 years of age and 5 years and over. In the present study, when regression lines were estimated and plotted and tests were made for the significance of the regression of length of gestation on the order of the reproductive cycle, the Ayrshire herd, and pooled data for all breeds, showed this regression to be highly significant at the 1 per cent level of probability. This indicates that older cows have longer gestation periods than younger cows.

\section{REPEATABILITY}

It has been assumed that length of gestation period is repeatable and that a cow which has a long or a short one will have gestation periods of similar length throughout her reproductive life. This was found not to be true in this study. The Jerseys had the highest repeatability (0.263) and the Holsteins the lowest $(-0.074)$, whereas the repeatability for Ayrshires was 0.253. When the data for all breeds were pooled, the average repeatability of length of gestation was found to be 0.049 . This indicates that there is essentially no correlation between the lengtl of repeated gestations on the same individual (see Table 5). Copeland (5) and Knott (20) agree that individual cows vary widely in length of gestation periods with very little, if any, tendency for repeatability. 


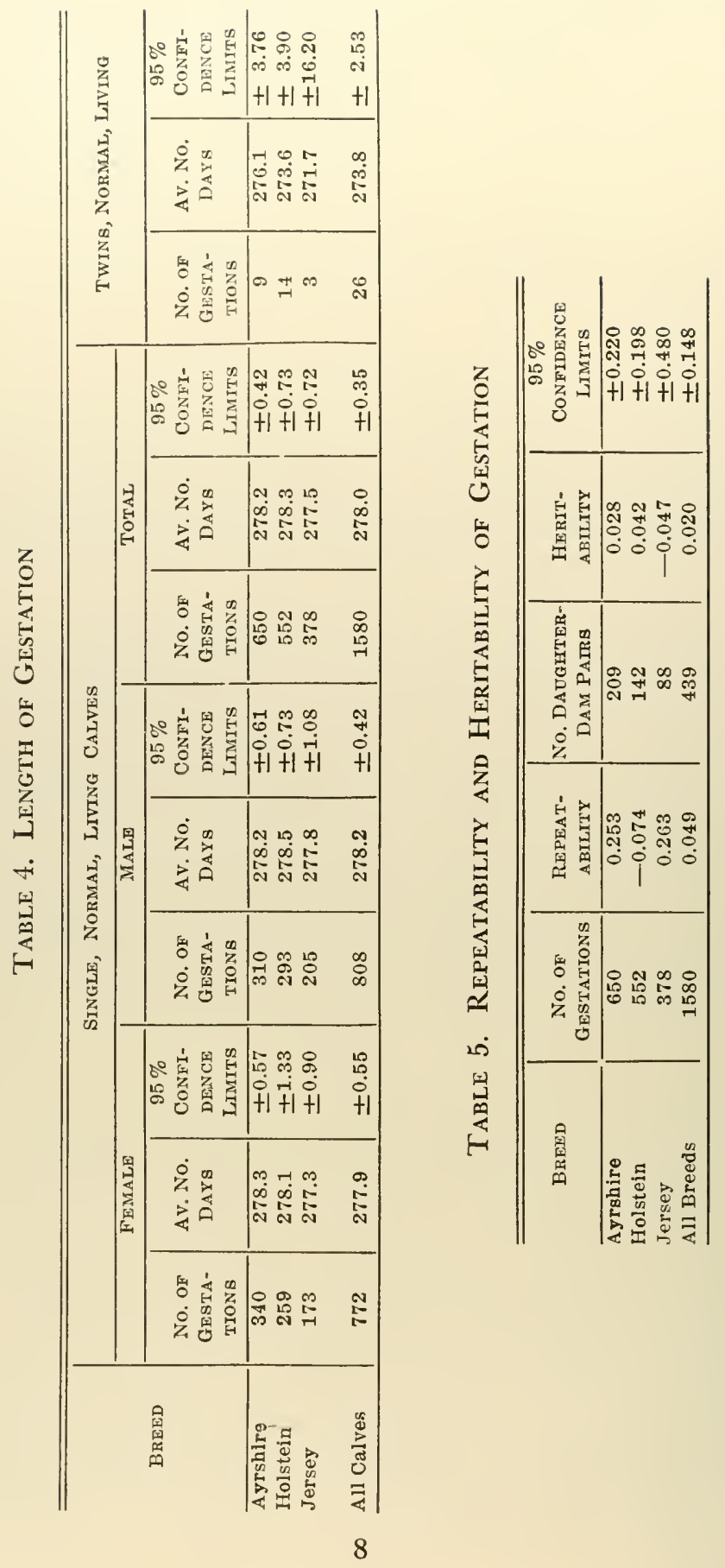




\section{HERITABILITY}

To determine the heritability of length of gestation, the gestation periods of dams and daughters were compared. In this study 439 daughter-dam pairs were used-209 Ayrshires, 142 Holsteins, and 88 Jerseys. The daughters were sired by 176 different bulls, with an average of 5.8 daughters per bull, ranging from 1 to 23 daughters. The heritability of the length of gestation (see Table 5) was estimated from the data to be 0.028 for the Ayrshire herd, 0.042 for the Holstein herd, and -0.047 for the Jersey herd, with an average of 0.020 when data for all herds were pooled. This would indicate that length of the gestation period is not heritable. These estimates are lower than those of Brakel (6) who reported correlation coefficients on 100 daughter-dam pairs of 0.32 in Ayrshires and 0.20 in Jerseys between the gestation period of the dams and their daughters.

\section{BREEDING EFFICIENCY}

Two measures of breeding efficiency were used in the study; namely (a) the number of services required per conception, and (b) the calving interval in days. The latter method was used both when only single, normal, living calves were included and when all calvings, including twins and calves dead at birth, were included.

\section{Number of Services Required per Conception}

The results of this part of the study are shown in Table 6. Breeding fficiency, measured by services per conception, averaged 1.79, 1.95, and ..27 for the Jersey, Holstein, and Ayrshire herds, respectively. The over11 average was 2.05 services per conception. The high average number If services per conception for the Ayrshire herd may be explained parially by the fact that a very real attempt has been made to keep every emale for at least one complete lactation. As a result, first-calf Ayrshire leifers which might have been discarded earlier as non-breeders were red more times than those of other breeds.

It has been thought that if an animal required several services for ne pregnancy, this would be repeated at other pregnancies. This was ot the case in this study. In many instances an animal that required everal services for one conception conceived on the first service during he next breeding period, and vice versa. A study of the repeatability of his factor showed a correlation between repeated records of only 0.006 then all breeds were considered (Ayrshire -0.130 , Holstein 0.057, Jersys 0.105 ). This reveals that the number of services required for coneption in one breeding period does not permit an estinate of the numer which might be required in the next period. 


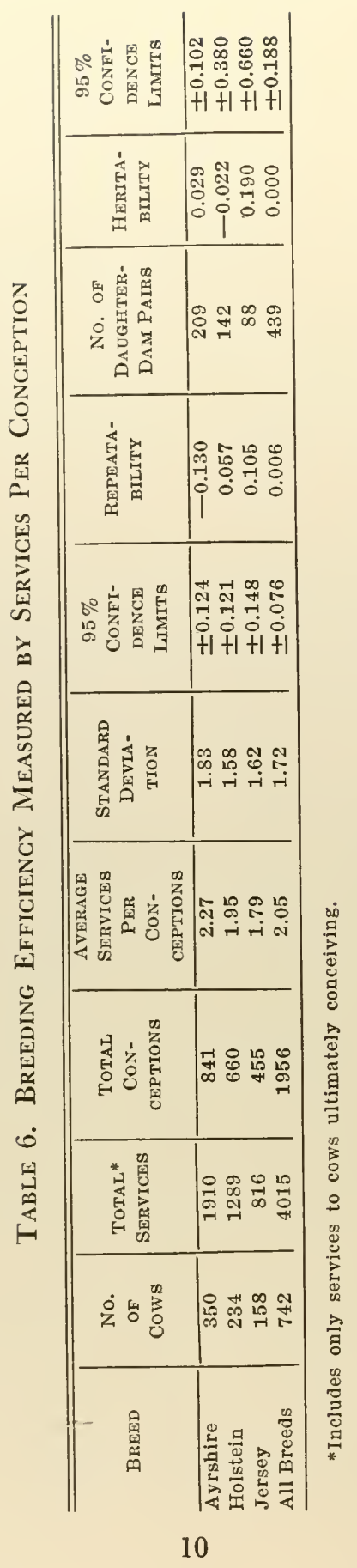


The heritability of the breeding efficiency, as measured by services per conception, was found to be 0.000 when data for all breeds rere pooled (Ayrshires 0.029; Holsteins -0.022 ; Jerseys 0.190). This relatively large value obtained for Jerseys is subject to very large sampling error as indicated by the 95 per cent confidence limits \pm 0.66 . These estimates strongly indicate that animals should not be selected on the basis of breeding efficiency based on services per conception, as the number of services required for one conception is neither repeatable nor heritable. These results agree with those of other workers $(7,21,24,29)$ who reported repeatability of services per conception and/or non-returns to first service to be so low as to be of no practical value. Although no estimates of heritability were presented, the works of Tanabe and Casida (26) and Trimberger and Davis (29) indicate that it is very low.

\section{Calving Interval}

It is commonly advised that 365 days is the ideal calving interval. Many problems of dairying would be solved if it were possible to have each cow in the herd calve each 12 months. Although 365 days is the ideal calving interval and should be striven for, it is seldom that such an interval can be maintained for the average cow in the herd. Some cows will fail to conceive when bred and, as a result, the calving interval will be lengthened. In the study under consideration, only gestations resulting in the birth of a normal, single, living calf were used. The average calving interval was 396.5 days when all breeds were included. The following are the results for the individual breeds: Ayrshire, 400.1 days; Holstein, 404.1 days; and Jerseys, 380.8 days. When all intervals were used, regardless of type of birth and viability, an average interval of 392.4 days was found for all breeds; Ayrshires, 399.3 days; Holsteins, 395.3 days; and Jerseys, 378.4 days. The results of this study are shown in Tables 7 and 8.

These tables also show that when either the interval between normal births or between all births was used as a measure of brecling efficiency, the repeatability estimates were so low that one must conclude that past records of calving interval on an individual are of no value in.predicting future calving intervals of the individual. These results differ somewhat from the work of Inchiosa and Pfau (15) and Wilcox and Pfau (30) who reported heritabilitics of 0.23 and 0.32 , respectively. Their methods estimated the heritability of the average calving interval rather than a single calving interval and thus would be expected to be higher.

\section{EfFect of Management on Calving Intervals}

It is interesting to note the trend in management in these herds over the past two or three decades as reflected by changes in the length of 


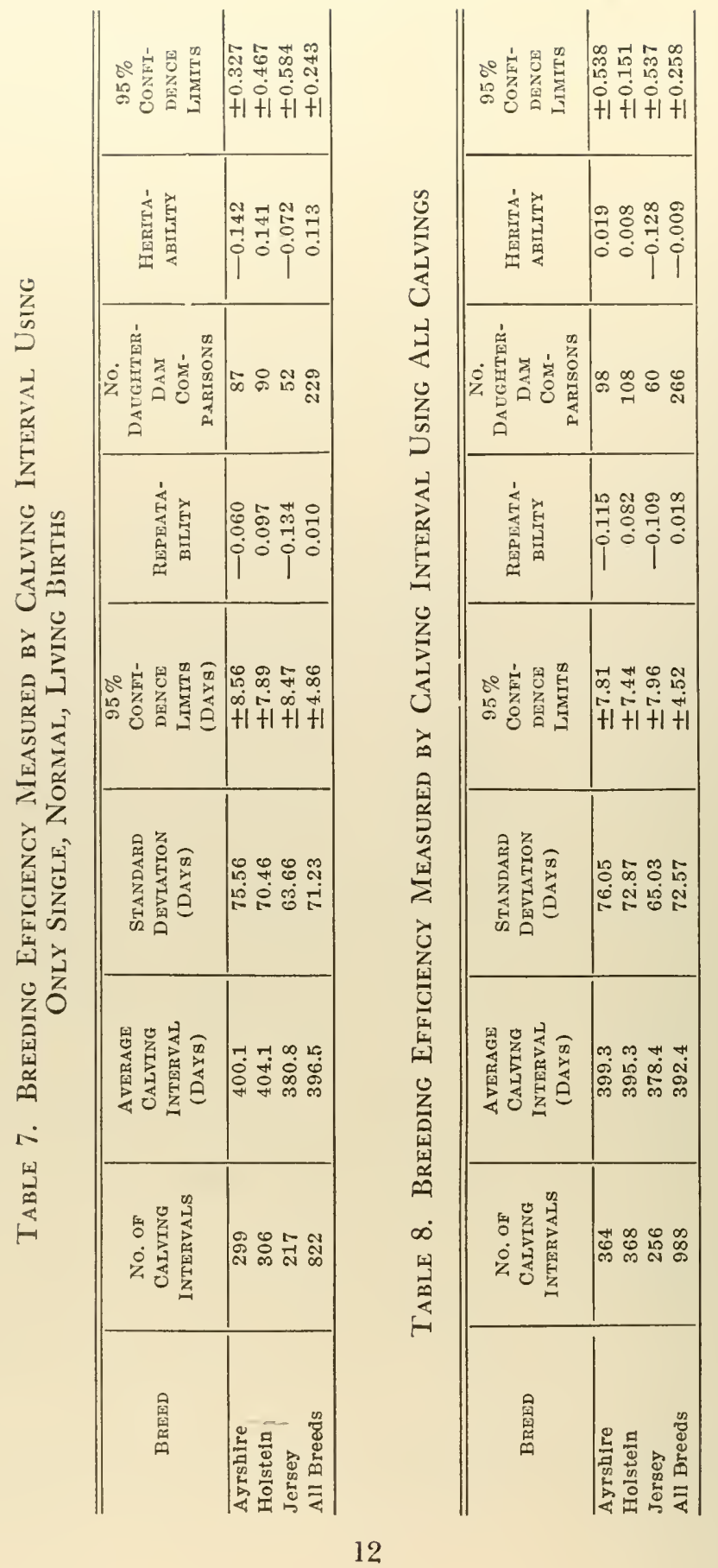


calving intervals. The data show a decrease in the lengths of calving interval for all of the breeds. However, when tests of significance of regression were made, only the Ayrshires showed a significant regression of length of calving interval on time. The Ayrshires declined from an average of 400 days in 1943 to 374.7 days in 1950. This indication of shorter calving intervals in all breeds, and the significant difference in the Ayrshires, is due partly to the increased emphasis by breed associations and experiment stations in stressing the value of the 305-day records in preference to the 365 -day records. It is also due partly to better herd management, which has resulted in fewer number of services per conception. The final result of these two factors is that the average calving interval is decreasing.

\section{Length of Calving Interval as Affected by Reproductive Cycle}

When the regression of the length of calving interval on order of reproductive cycle was calculated for all calvings and for single, normal, living calves, the Holsteins showed a significant decrease $(b=-4.867$ and -5.559 , respectively), in calving interval as the age of the dam, or more correctly, order of reproductive cycle increased. Ayrshires also showed a slight decrease $(b=-0.035$ and -2.376 , respectively) and all breeds ( $b=-1.79$ and -2.20 , respectively) showed a slight decrease, but the Jersey calving interval increased slightly as age of dam increased. This was undoubtedly due in part to changes in management associated with time and to change from 365-day to 305-day lactation periods. The calving interval might be expected to increase as reproductive cycle order increased because of selection for other traits. Dairymen usually permit the good brood cows more services, when necessary, than they will young, unproven brood cows. Therefore, this indication that the length of calving interval decreases as reproductive cycle increases is thought to be confounded with time trends, since there was an indication that the average calving interval decreases with time.

Many herdsmen speak of certain cows in their herd as being "hard breeders" and certain cow families within their herd as having a low breeding efficiency. Many dairymen have gone so far as to select for high breeding efficiency, but on the basis of this study and studies reported by other workers, it seems very likely that any success they have had was due to improved enviromental and management conditions rather than to inheritance. On the basis of these data, and investigations of others, it would seem that selection for high fertility in terms of services per conception, or calving interval, cannot be very effective and that consideration of these traits would serve only to decrease the effectiveness of selection for such traits as milk and butterfat production and type conformation. 


\section{Summary and Conclusions}

Reproduction data based on 4,015 services, 1,956 conceptions, and 1,580 gestations in the Reymann Memorial Ayrshire and West Virginia University Holstein and Jersey herds were summarized. This included various aspects of reproduction such as breeding efficiency, length of gestation, birth weights, sex ratios, and viability of offspring. Estimates of how accurately one could predict the length of gestation, services per conception and calving intervals from past records on an individual and records on her relatives were also obtained.

These results should provide a better understanding of reproduction and result in a more accurate knowledge of the relative emphasis to place on the several traits involved in a selection program. Some of the results of this investigation follow:

1. Sex Ratios-The sex ratio for all breeds was 106.4 males to 100 females for single calves. When only twin births were considered, a ratio of 66.7 males to 100 females was found. This was not significant at the 95 per cent level, although it did approach significance. There was also insufficient evidence to conclude that sex was influenced by reproductive cycle, service, or viability.

2. Mortality of Offspring-All breeds combined gave birth to 52 living twin calves and 28 dead twin calves, or 35.0 per cent dead at birth as compared to only 5.7 per cent of the single calves being born dead. The difference between the viability of twins and single calves was highly significant, indicating conditions in the uterus are less favorable to twins than to single calves.

3. Gestation-The average length of gestation was 278.0 days for all breeds combined with a total of 1,580 births. Breed averages were: Ayrshires 278.2, Holsteins 278.3, and Jerseys 277.5 days. This indicates that the average gestation is approximately five days less than the figure of 283 which is widely used. Repeatability and heritability estimates of gestation length were 0.049 and 0.020 , respectively, which indicates that past records on an individual or her relatives are of no value in predicting the length of future gestations. This is further justification for using the mean length of 278 days. Confidence limits at the 95 per cent level of probabliity on the heritability estimates were \pm 0.148 , and the same limits on the average gestation were \pm 0.35 .

4. Breeding Efficiency-Three different measures of reproductive efficiency were used to determine how effective selection for this trait could be. They were: (a) Services-per conception-an average of 2.05 services were required per conception. Repeatability and heritability estimates were 0.006 and 0.000 , respectively, (b) calving intervals of all calvings regardless of type of birth or viability-the average calving interval was 
392.4 days for 988 intervals. Repeatability and heritability estimates were -0.018 and -0.009 , respectively, and (c) calving intervals of single, normal, living calves-a total of 822 intervals averaged 396.5 days. Repeatability and heritability estimates were 0.010 and 0.113 , respectively.

On the basis of these results, it is concluded that selection for fertility in dairy cattle, as measured by services per conception or calving intervals, would not be effective. Any emphasis placed on selection for this trait would only reduce the progress made in seletcion for other traits of economic importance.

\section{References}

1. Alexander, M. H., "Length of Gestation in the Five Major Breeds of Dairy Cattle." J. Dairy Sci., 33:377. 1950.

2. Arnold, P. T. D., and Becker, R. B., Dairy Calves-Their Development and Survival. U. of Florida Agr. Expt. Sta. Bul. 529. 1953.

3. Baker, A. L., and Queensberry, J. R., "Fertility in Range Beef Cattle." J. Animal Sci., 1:344. 1942.

4. Brakel, W. J., Rife, D. C., and Salisbury, S. M., "Factors Associated with the Duration of Gestation in Dairy Cattle." J. Dairy Sci., 35:179. 1952.

5. Copeland, L., "Length of Gestation in Jersey Cows." J. Dairy Sci., 13:257. 1930.

6. Davis, H. P., Dairy Calf Births and Disposals. Neb. Agr. Expt. Sta. Bul. 411. 1952.

7. Dunbar, R. S. Jr., and Henderson, C. R., "Heritability of Fertility in Dairy Cattle." J. Dairy Sci., 34:1063. 1953.

8. Eckles, C. E., and Anthony, E. L., Dairy Cattle and Milk Production. The Macmillan Co. 1956.

9. Fitch, J. B., McGilliard, P. C., and Drum, G. M., "A Study of the Birth Weights and Gestation of Dairy Animals at Kansas State College." J. Dairy Sci., 7:222. 1924.

10. Fohrman, M. H., and Graves, R. R., Experiments in Breeding Holstein-Friesian Cattle for Milk and Butterfat Producing Ability and of the First Outbred Generation. U.S.D.A. Tech. Bul. 667. 1939.

1. Gilmore, L. O., Dairy Cattle Breeding. F. B. Lippincott Co. 1952.

2. Gowen, J. W., "Sex Ratio in Cattle." J. Heredity, 33:299. 1942.

3. Herman, H. A., Spalding, R. W., and Bower, K. W., Factors Affecting Length of Gestation in Dairy Cattle. U. of Mo. Res. Bul. 529. 1953.

4. Hilder, R. A., Fohrman, M. H., and Graves, R. R., "Relation of Various Factors to the Breeding Efficiency of Dairy Animals and to the Sex Ratio of the Offspring." J. Dairy Sci., 27:981. 1944.

5. Inchiosa, M. A., and Pfau, K. O., "The Influence of Dams and Sires Upon the Breeding Efficiency of 'Their Daughters Within a Holstein-Friesian Herl." J. Dairy Sci., 37:667. 1954.

6. Jafar, S. M., Chapman, A. B., and Casida, L. E., "Causes of Variations in Length of Gestation in Dairy Cattle." J. Animal Sci., 9:593. 1950.

7. Johansson, I., "Conclusions on Sex Inheritance." Jersey Bulletin, 51:332. 1932. 
18. Jones, I. R., Dougherty, R. W., and Haag, J. R., Reproductive Performance in Dairy Cattle. Oregon Agr. Expt. Sta. Bul. 395. 1941.

19. Knopp, C. E., and Hayden, C. C., A Study of the Length of Gestation and Service Records of Dairy Cows. Ohio Agr. Expt. Sta. Bul. 395. 1941.

20. Knott, J. C., "A Study of the Gestation Period of Holstein-Friesian Cows." J. Dairy Sci., 15:87. 1932

21. Legates, J. E., "Genetic Variation in Services Per Conception and Calving Intervals." J. Animal Sci., 13:81. 1954.

22. Lush, J. L., "Intra-Sire Correlation or Regressions of Offspring on Dam as a Method of Estimating Herbitabilities of Characteristics." Proc. Am. Soc. Animal Prod., 33:293. 1940.

23. Morgan, R. F., and Davis, H. P., Influence of Age and Dairy Cattle and Season of the Year on the Sex Ratio of Calves and Services Required for Conception. Neb. Agr. Expt. Sta. Bul. 104. 1938.

24. Olds, D., and Seath, D. M., "Predictability of Breeding Efficiency in Dairy Cattle." J. Dairy Sci., 33:721. 1950.

25. Olson, T. M., Elements of Dairying. The Macmillan Co. 1950.

26. Tanabe, T. Y., and Casida, L. E., "The Nature of Reproductive Failures in Cows of Low Fertility." J. Dairy Sci., 32:237. 1949.

27. Tanabe, T. Y., and Salisbury, G. W., "The Influence of Age on Breeding Efficiency of Dairy Cattle in Artificial Insemination." J. Dairy Sci., 29:337. 1946.

28. Taylor, G. E., "Some Factors Affecting Breeding Efficiency in Dairy Cattle." Mich Agr. Expt. Sta. Quarterly Bul. 19:156. 1937.

29. Trimberger, G. W., and Davis, H. P., "Predictability of Breeding Efficiency ir Dairy Cattle from Their Previous Conception Rate and from Their Heredity.' J. Dairy Sci., 28:65̃9. 1945.

30. Wilcox, C. J., and Pfau, K. O., Longevity of Dairy Cows Within a Holstein. Friesian Herd: An Estimate of Its Heritability and Its Relationship with Breeding Efficency. Paper presented at Eastern Section, American Dairy Science Association 1954. 